\title{
The Constitutional Right to Lobby on the Two Sides of the Atlantic: Between Freedom and Democracy
}

\author{
Riccardo de Caria*
}

\begin{abstract}
The article reviews the main constitutional arguments for the protection of lobbying brought about in the United States and in the European Union, putting such arguments in a legal history context. After explaining the relevance and topicality of the study of lobbying from a constitutional law perspective (Part 1), attention is paid to the issue of properly defining lobbying (Part 2). The article then outlines the key features of the law of lobbying in the two legal systems considered (Part 3), and then links this analysis with some broader reflections on free speech and democracy in the two areas considered, in order to show how different is the way in which the two areas conceptualize a constitutional 'right to lobby' (Part 4). The final paragraph offers some concluding remarks, making a few policy recommendations (Part 5).
\end{abstract}

\section{Lobbying and constitutional law}

In recent years, both in the United States and in the European Union, lobbying has been the subject of much attention in the public debate, mostly triggered by scandals that have involved high-ranking officials and prominent lobbyists. ${ }^{1}$

\footnotetext{
Ph.D (Università di Torino), LLM (London School of Economics and Political Science). I would like to thank very much Professor Martin A. Rogoff (Maine Law School), Professor Elisabetta Palici di Suni (Università di Torino), Dr Jan Komárek (LSE), Dr Pablo Ibáñez Colomo (LSE), Domenico Monea (Università di Torino) and the anonymous reviewers for their extremely valuable comments and observations.

1 The stories that caused the biggest stir concerned, respectively, Jack Abramoff in the US (see R Kaiser, So Damn Much Money. The Triumph of Lobbying and the Corrosion of American Government
}

Copyright (c) the Author(s).

This work is licensed under a Creative Commons Attribution-NonCommercial-NoDerivs 3.0 License. 
Consequently, many of the views expressed about lobbying, from both sides of the ideological spectrum, are critical of this practice, and of the influence that organised interests are able to exert on the democratic political process this way. ${ }^{2}$ Some people would suggest that lobbying is not much more than a form of legalised corruption: US President Obama himself has repeatedly echoed this line of thought, during his campaign for the presidency and once in office. ${ }^{3}$ However, many lobbyists and civil libertarians reject these charges, arguing that lobbying is a form of political expression; therefore, it cannot be restricted without infringing both certain crucial tenets of democracy and certain fundamental individual rights, chiefly what in the US are called 'First Amendment freedoms', in particular freedom of speech, freedom of association, and freedom to petition the government. ${ }^{4}$

Freedom of expression and democracy are the two opposing poles that frame the debate over lobbying. It is, therefore, to a great extent a constitutional debate: both sides rely heavily on constitutional principles to argue that lobbying must or must not be restricted. Without taking sides in this debate, this article contrasts how such arguments were developed in the legal systems of the US and the EU, and how they are reflected in the respective rules on lobbying. ${ }^{5}$ A relatively

(2009), 3-24) and the 'cash-for-laws' scandal in the EU Parliament, exposed by the Sunday Times with a series of articles in March 2011 (see e.g. "Euro MPs exposed in "cash-for-laws" scandal' Sunday Times, 20 March 2011, <http://www.thesundaytimes.co.uk/sto/news/insight/art icle582604.ece $>$ [accessed 25 July 2013]).

2 A classic critique of the power of interest group is the one by T J Lowi, The End of Liberalism: The Second Republic of the United States (2nd edn, 1979). See also B Judis, The Paradox of American Democracy: Elites, Special Interests, and the Betrayal of Public Trust (2000).

3 Besides attacking the power of lobbyists in many interviews and speeches, he also refused to accept contributions from lobbyists for his first presidential campaign. On his first day in office of his first term he signed an Executive Order, Ethics Commitments by Executive Branch Personnel, dictating a series of strict rules with which the administration officials have to comply in their relationships with lobbyists. See also R L Hasen, 'Lobbying, Rent Seeking and the Constitution' (2012) 64 Stan LR 191, 204-207. Some challenges have been brought to some of the new rules introduced by the Obama administration, but they have been rejected so far: see K Bogardus, 'Federal court tosses out lawsuit challenging Obama's lobbyist ban' The Hill, 26 September 2012, <http://thehill.com/business-a-lobbying/258785-judge-tosses-out-lawsuitagainst-obamas-lobbyist-ban $>$ [accessed 25 July 2013].

4 See generally H Eastman, Lobbying: A Constitutionally Protected Right (1977); more broadly on the debate over the existence or not of a constitutional right to lobby, see below n 25 and accompanying text.

5 Clearly, the US and the EU are not homogeneous polities, the former being a single federal state, while the latter being a union of still sovereign states (to be sure, the US is not a unitary entity either: every state has its own legislation, autonomous from the federal model). However, 
detailed analysis of such rules will show some unexpected results. On the one hand, I will show that, at first sight, the two regulatory frameworks are more similar than one might anticipate. Indeed, the restrictions to lobbying activities, however different in the two areas under consideration, are motivated by the same goal of transparency. On the other hand, though, such transparency goal is brought about against the background of different legal systems and different legal histories, which leads me to submit that beneath the surface of this apparent similarity lies a rather significant divergence in the theoretical justifications for the respective regulations.

While the First Amendment to the US constitution was passed in a little institutionalised environment, reflected in its 'uncompromised' structure, ${ }^{6}$ current European constitutional documents were drafted with a much heavier historical and institutional background, which led to a more qualified protection of the freedom of expression. This might partially account for the fact that lobbying in the US is practiced more openly and in more venues, while in Europe it remains an activity that cannot even be called by its own name (but needs synonyms to be referred to), and tends to be confined to the law-making forum. It is finally submitted that, on its turn, this is connected to the nature of the legal systems considered: it is arguably the flexible common law system that leaves more room for lobbying at different levels, and also for idealistic, non-economic, grassroots lobbying, whereas the more rigid civil law system leads to concentrate lobbying efforts on legislators, and tends not to leave much room for grassroots lobbying, thus affording a competitive advantage to organisations lobbying for business reasons.

This article is structured in the following way: first, I will define exactly what is meant by lobbying from a regulatory point of view (Part 2). After that, I will analyse the essentials of lobbying regulation in the US and the EU; the most relevant sources for the purposes of this article will be the Supreme Court's case law in the US and certain non-legislative documents from EU institutions (Part 3). After that, I will investigate the different ways in which the two areas under consideration conceptualise a constitutional 'right to lobby', and on the

the way lobbying is conducted in the District of Columbia does not differ substantially from the practice of lobbying in Brussels; more importantly, the EU can regulate the lobbying of its institutions with substantially the same powers as the US with respect to federal government. Therefore, constrasting the two models seems a legitimate exercise of comparison.

6 On the history of the First Amendment, see e.g. A R Amar, The Bill of Rights: creation and reconstruction (1998), 20-45; for an historical overview, see also C R Sunstein, Interest Groups in American Public Law' (1985) 38 Stan LR 29. 
implications of such different approaches (Part 4). Finally, I will draw conclusions on why, despite the asymmetry in the comparison between lobbying law in the US and in the EU, such comparison is still a worthwhile effort (Part 5).

\section{Lobbying defined}

According to Webster's Dictionary, to 'lobby' means '[t]o address or solicit members of a legislative body in the lobby or elsewhere, with the purpose to influence their votes.' Similarly, Black's Law Dictionary defines the verb 'lobby' as: '1. To talk with or curry favor with a legislator, usually repeatedly or frequently, in an attempt to influence the legislator's vote. 2. To support or oppose (a measure) by working to influence a legislator's vote. 3 . To try to influence (a decision-maker), ${ }^{8}$ Broadly speaking, then, lobbying refers to the attempt by anyone, for any reason, to persuade a public official to take any sort of decision on any topic (from the enactment or rejection of a bill or any other regulation, to the funding of a certain project, to the appointment of someone to a public office, and so on). As such, lobbying is well known everywhere in the world, and has presumably existed as long as politics itself, at least in its modern version typical of representative democracies: as soon as we have people who have the power to take decisions on behalf of a whole community, there will always be somebody interested in persuading them to decide in one way or another.

However, what I am interested in here, and is the distinctive feature of the legal systems that regulate lobbying-traditionally the US and now also the EU-is only professional lobbying, i.e. the pressure exerted on public officials by interest groups as part of their day-to-day business. Interest groups can practice lobbying in-house, or outsource it to lobbying firms, but in both cases those who actually perform this activity are professionals highly specialised in dealing with public officials, and in the subject matters in which those whom they represent are active. In this article, I am concerned with the rules and the constitutional principles that govern the activity of these professionals, whose job it is to 'lobby', and who can be described as 'stable intermediaries' between interest groups, on the one hand, and politics, on the other. Indeed, such professionals develop a deep knowledge of the law-making process, as well as the rules regulating the activity of government agencies enforcing the law, and have a personal acquaintance with

\footnotetext{
7 Webster's Revised Unabridged Dictionary (1913) <http://www.encyclo.co.uk/webster2/search.php> [accessed 25 July 2013] (entry for 'lobby' when used as an intransitive verb) .

8 Black's Law Dictionary (9th edn, 2009), (entry for 'lobby').
} 
many of the people involved in these circuits. Private interests turn to lobbyists because the lobbyists know the right people to talk to about an issue they are concerned with, and often have some personal connection with them that they have cultivated over time. In this sense, lobbyists intermediate between private parties and politics, and do it stably, as their job, acting on a regular basis as a drive belt between the polity, on the one hand, and the policy-makers, on the other (I will come back on the notion of 'stable intermediaries' in Part 4).

The principal US federal law on the subject, the Lobbying Disclosure Act 1995 (LDA), is solely concerned with professional lobbying. S 3 of the LDA does not contain a definition of lobbying itself, but it stipulates that 'lobbying activities' are:

lobbying contacts and efforts in support of such contacts, including preparation and planning activities, research and other background work that is intended, at the time it is performed, for use in contacts, and coordination with the lobbying activities of others. ${ }^{9}$

In turn, a 'lobbying contact' is to be considered:

any oral or written communication [...] to a covered executive branch official or a covered legislative branch official that is made on behalf of a client with regard to-(i) the formulation, modification, or adoption of Federal legislation [...]; (ii) the formulation, modification, or adoption of a Federal rule, regulation, Executive order, or any other program, policy, or position of the United States Government; (iii) the administration or execution of a Federal program or policy [...]; or (iv) the nomination or confirmation of a person for a position subject to confirmation by the Senate. ${ }^{10}$

Finally, s 3 of the LDA also clarifies who is a 'lobbyist'. A quantitative criterion is used:

The term 'lobbyist' means any individual who is employed or retained by a client for financial or other compensation for services

\footnotetext{
9 Lobbying Disclosure Act 1995 (US) 2 USC $\$ 1602$.

${ }^{10}$ Ibid, s 3. The 'covered executive branch official' means the President, the Vice-President, the members of the cabinet and their staff, while the 'covered legislative branch official' means the members of Congress, their staff and the staff of parliamentary commissions.
} 
that include more than one lobbying contact, other than an individual whose lobbying activities constitute less than 20 percent of the time engaged in the services provided by such individual to that client over a 3-month period. ${ }^{11}$

The 20 percent threshold has been criticised as arbitrary, difficult to measure, and therefore relatively easy to circumvent, ${ }^{12}$ but it is currently the relevant distinctive criterion in the law.

As far as EU law is concerned, as we shall see the bulk of lobbying regulation is still of a non-mandatory nature, so there are no binding documents containing an official definition, comparable to the one of the LDA. However, a definition of lobbying' was provided by the Green Paper entitled 'European Transparency Initiative', presented by the Commission on 3 May 2006: according to it, "lobbying" means all activities carried out with the objective of influencing the policy formulation and decision-making processes of the European institutions.'13

The recent 'Agreement between the European Parliament and the European Commission on the establishment of a transparency register for organisations and self-employed individuals engaged in EU policy-making and policy implementation' (Transparency Register Agreement), includes an analytical description of the activities covered. Article 8 stipulates that:

The scope of the register covers all activities [...] carried out with the objective of directly or indirectly influencing the formulation or implementation of policy and the decision-making processes of the EU institutions, irrespective of the channel or medium of communication used, for example outsourcing, media, contracts with professional intermediaries, think-tanks, platforms, forums, campaigns and grassroots initiatives. These activities include, inter alia, contacting Members, officials or other staff of the EU institutions, preparing, circulating and communicating letters, information material or discussion papers and position papers, and organising events, meetings or promotional activities and social events or

${ }^{11}$ Ibid, s 3. The period was six months before the overhaul by the Honest Leadership and Open Government Act of 2007, s 201(b).

12 See W Luneburg, 'The Evolution of Federal Lobbying Regulation: where we are now and where we should be going' (2009) 41 McGeorge LR 85, 91-92, 119.

${ }^{13}$ European Commission, Green Paper: European Transparency Initiative, 3 May 2006, 5 <http://ec.europa.eu/transparency/eti/docs/gp_en.pdf> [accessed 25 July 2013]. 
conferences, invitations to which have been sent to Members, officials or other staff of the EU institutions. Voluntary contributions and participation in formal consultations on envisaged EU legislative or other legal acts and other open consultations are also included. ${ }^{14}$

The Agreement does not use the word lobbying, but within the context of this article its description will be the benchmark for the definition of this activity under EU law.

\section{Distinguishing features of the law of lobbying in the US and in the EU}

We can now move to outline the essential aspects of the law and case law concerning lobbying in the US and in the EU. It is clearly outside the scope of this work to go into the details of lobbying regulation: as explained in Part 1, I will just briefly describe the features that are most important for the sake of contrasting the constitutional aspects of the problem.

\subsection{The law of lobbying in the US}

For many decades, there was only piecemeal regulation of lobbying in the US. ${ }^{15}$ Nonetheless, the Supreme Court had a chance to express its view of this activity in a line of cases between the end of the 19th century and the beginning of the 20th, concerning the enforcement of lobbying contracts with a contingent fee clause (i.e. where the fee to be paid was contingent on whether the lobbying effort had been successful or not). In these rulings, ${ }^{16}$ the Supreme Court held such contracts unenforceable, because they posed too big a threat of corruption and of sacrificing the common interest for the sake of private benefits. In fact, in its reasoning, the Court was severely critical of the practice of lobbying itself, stating, for example, in the most important of these cases, that:

\footnotetext{
${ }^{14}$ Transparency Register Agreement, 22 July 2011, <http://eur-lex.europa.eu/LexUriServ/Lex UriServ.do?uri=OJ:L:2011:191:0029:0038:EN:PDF> [accessed 25 July 2013] Part IV, Art 8. Art. 10 of the Transparency Register Agreement then lists a series of 'Activities excluded'.

${ }^{15}$ See W N Eskridge Jr, 'Federal Lobbying Regulation: History Through 1954', in W V Luneburg, T M Susman \& R H Gordon (eds), The Lobbying Manual: A Complete Guide to Federal Lobbying Law and Practice (4th edn, 2009), 5-21.

${ }^{16}$ Marshall v Baltimore and Ohio Railroad Co, 57 US 314 (1853); Providence Tool Co v Norris, 69 US 45 (1864); Trist $v$ Child, 88 US 441 (1874); Hazelton $v$ Sheckels, 202 US 71 (1906).
} 
If any of the great corporations of the country were to hire adventurers who make market of themselves in this way, to procure the passage of a general law with a view to the promotion of their private interests, the moral sense of every right-minded man would instinctively denounce the employer and employed as steeped in corruption and the employment as infamous. ${ }^{17}$

However, in the following decades, things changed. First, the Supreme Court distinguished its precedents on contingent fee lobbying in a 1927 case, $^{18}$ where it held that a contract was not automatically contrary to public policy for merely contemplating an 'undertaking to procure the passage of [...] ordinances': in this particular case, the contract under consideration did not 'requir[e] or contemplat $[\mathrm{e}]$ the obtaining of legislative or executive action as a matter of favor by means of personal influence, solicitation, and the like, or by other improper or corrupt means', and was therefore to be considered valid and enforceable. Then, two decades later, in 1946, the first comprehensive law on lobbying was enacted, the Federal Regulation of Lobbying Act (FRLA). ${ }^{19}$ The FRLA imposed on lobbyists some duties of registration and disclosure. By choosing to regulate lobbying (even though targeting only legislative lobbying, leaving unregulated the lobbying of the executive), Congress implicitly recognised the legitimacy of the activity: as long as lobbying was carried on in compliance with the FRLA, it was not illegal. This reflected a very different attitude towards lobbying, that a few years later surfaced in the Supreme Court, too. The Court first raised some 'doubts of constitutionality' with regard to restrictions of lobbying activities in a 1953 case United States $v$ Rumely, which did not relate to the FRLA but was in anyway crucial. ${ }^{20}$ That case involved the interpretation of the powers of the House Committee on Lobbying Activities, that was entrusted with the task of investigating 'all lobbying activities intended to influence, encourage, promote, or retard legislation.' ${ }^{21}$ The Court held that the phrase 'lobbying activities' had to be interpreted narrowly, because otherwise the powers of inquiry of the Committee would have been too broad, and would have encroached upon the 'prohibition of the First Amendment. ${ }^{22}$ It was therefore not lobbying itself that had to be

\footnotetext{
17 Trist $v$ Child, 88 US 441 (1874), 451.

${ }^{18}$ Steele v Drummond, 275 US 199 (1927).

${ }^{19}$ Legislative Reorganization Act 1946 (US) Title III.

${ }^{20}$ United States $v$ Rumely, 345 US 41(1953), 46.

${ }^{21}$ House Resolution 298, 81st Cong., 1st Session, 12 August 1949.

${ }^{22}$ United States $v$ Rumely, above n 20, 46.
} 
limited, but rather restrictions on it, in order not to infringe a constitutional right. In particular, Rumely made it clear for the first time that any regulation of lobbying had to be carefully drafted in order to avoid limiting the freedoms strongly protected by the First Amendment.

This reasoning was the underpinning for a challenge to the FRLA the next year: petitioners argued that the registration and disclosure requirements violated their 'freedoms guaranteed by the First Amendment-freedom to speak, publish, and petition the Government. ${ }^{23}$ In what is still the leading case on lobbying decided by the US Supreme Court, United States $v$ Harriss, Chief Justice Warren, writing for the majority, gave a narrow interpretation of the sections establishing the field of application of the new duties. However, he concluded that, thus interpreted, such duties were permissible; indeed, for the 'full realization of the American ideal of government by elected representatives', Congress should be able to know to which pressures it is being subjected. ${ }^{24}$

Harriss fell short of finding a 'constitutional right to lobby', something that, according to many commentators, was never really acknowledged by the Court. ${ }^{25}$ However, following the reasoning already suggested by the dissenters in Harriss, ${ }^{26}$ the Court in its later Noerr $^{27}$ decision affirmed that the whole concept of representation depends upon the ability of the people to make their wishes known to their representatives, ${ }^{28}$ and accordingly that lobbying was a legitimate activity

\footnotetext{
${ }^{23}$ United States $v$ Harriss, 347 US 612 (1954), 625.

${ }^{24} \mathrm{Ibid}, 625$.

${ }^{25}$ See e.g. S A Browne, "The Constitutionality of Lobby Reform: Implicating Associational Privacy and the Right to Petition the Government' (1995) 4 William \& Mary Bill of Rights Journal 717, 729-732; A P Thomas, 'Easing the Pressure on Pressure Groups: Toward a Constitutional Right to Lobby' (1993) Harv J of L \& Public Policy 149, 150. Instead, A B Morrison, 'Introduction: Lobbyists-Saints or Sinners?' (2008) 19 Stan L \& Policy Rev 1, 1 simply writes that 'as all the authors recognize, the right to lobby is the right to petition the government for redress of grievances, which is explicitly protected by the First Amendment'.

${ }^{26}$ Justices Douglas, Black \& Jackson. See especially United States $v$ Harriss, above n 23, 635 (Jackson J): 'the First Amendment forbids Congress to abridge the right of the people "to petition the Government for a redress of grievances". If this right is to have an interpretation consistent with that given to other First Amendment rights, it confers a large immunity upon activities of persons, organizations, groups and classes to obtain what they think is due them from government. Of course, their conflicting claims and propaganda are confusing, annoying, and, at times, no doubt, deceiving and corrupting. But we may not forget that our constitutional system is to allow the greatest freedom of access to Congress, so that the people may press for their selfish interests, with Congress acting as arbiter of their demands and conflicts'.

${ }^{27}$ Eastern Railroad Presidents Conference v Noerr Motor Freight Inc, 365 US 127 (1961) (opinion by Justice Black, who dissented in United States $v$ Harriss, above n 23).

${ }^{28}$ Ibid, 137.
} 
even when it had anti-competitive effects. In a more recent case, Regan $v$ Taxation With Representation, ${ }^{29}$ Justice Blackmun (joined by Brennan and Marshall JJ), in his concurrence even wrote that 'lobbying is protected by the First Amendment. ${ }^{\text {' }}$ Therefore, the idea developed that limitations on lobbying could not go beyond a certain threshold: registration and disclosure were deemed not to infringe First Amendment rights, but the First Amendment has become the 'elephant in the room' in any effort to regulate lobbying. The Court never explicitly invoked it to strike down any lobbying law, but legislators knew that this chance was always there, if they went too far in restricting this activity. This case law was, indeed, known to the Congress when, in 1995, it finally reached a consensus on replacing the FRLA with a new law of lobbying (that also covers lobbying of the executive branch), after such change had been advocated from different sides for many years. This new law is the already mentioned LDA. ${ }^{31}$

The underlying thread of the LDA, as is clear from the title, is the duty of disclosure: except for registration in the register of lobbyists, the LDA does not impose any particular limit to this activity or to how to carry it on. The only condition for the LDA is that certain relevant information is recorded and made public through periodic reports. Harriss, although relative to the FRLA, is still controlling for the legitimacy of these disclosure obligations imposed on lobbyists, given the identity of rationale of the FRLA and the LDA in this respect: the LDA also makes it clear that nothing in it 'shall be construed to prohibit or interfere with-(1) the right to petition the Government for the redress of grievances; (2) the right to express a personal opinion; or (3) the right of association, protected by the First Amendment to the Constitution. ${ }^{32}$ The LDA is still the most relevant regulation of lobbying in the US (even if it has been amended several times, the most important of which is by the Honest Leadership and Open Government Act of 2007). In past years, however, there have been significant developments that may eventually lead to a new pronouncement of the Supreme Court. In particular, the landmark campaign finance case Citizens United $v$ Federal Election Commission (Citizens United), ${ }^{33}$ where the Supreme Court held that the prohibition on corporations (and unions) to contribute from their general treasury funds to political campaigns, violated those entities' First Amendment

\footnotetext{
${ }^{29}$ Regan $v$ Taxation With Representation, 461 US 540, 552 (1983).

${ }^{30}$ Ibid, 552.

${ }^{31}$ LDA, above n 9, Part II. For a comment, see e.g. Luneburg, Susman \& Gordon, above n 15, Chapters 3-6.

${ }^{32}$ LDA, above n 9 , s $8(\mathrm{a})$.

${ }^{33} 558$ US 50 (2010).
} 
political rights, is starting to have effects in the closely connected field of lobbying. ${ }^{34}$

Relying on Citizens United's strong stand in favour of the freedom of everyone to influence the political process to the best of his ability, the US Court of Appeal for the Second Circuit in Green Party of Connecticut $v$ Garfield, and a federal district court in Ohio in Brinkman $v$ Budish struck down, respectively, 'a Connecticut law that barred campaign contributions to state candidates by lobbyists' and 'a law barring lobbyists from engaging in fundraising', on the one hand, and 'a "revolving door" statute that barred former state legislators and staffers from lobbying the legislature for 12 months after leaving service, ${ }^{35}$ on the other. This litigation never ended up in the Supreme Court, which would have presumably confirmed the legitimacy of disclosure rules; ${ }^{36}$ however, in the future, the Court might strike down laws that impose further obligations, ${ }^{37}$ on the grounds that they risk 'chilling' some political speech that would otherwise contribute to public debate: an explicit acknowledgment of a First Amendment right to lobbying, thus, may be on its way.

\subsection{The law of lobbying in the EU}

Moving to EU law, the first thing to notice is that rules are provided only relative to the Commission and the Parliament: there is no regulation for lobbying the other institutions, including the European Council and the Council of the European Union. For a long time, the existing rules were separate for the Commission and the Parliament. They have been unified only recently.

The first official document dealing with the issue dates back only to 1992, when the Commission issued the policy paper 'An open and structured dialogue between the Commission and interest groups.' ${ }^{38}$ This paper would not lead

\footnotetext{
${ }^{34}$ On the links between lobbying and campaign finance, see R Briffault, 'Lobbying and Campaign Finance: Separate and Together' (2008) 19 Stan L \& Policy Rev 105; after Citizens United, ibid, see H Gerken, 'Lobbying as the New Campaign Finance' (2011) 27 Georgia State ULR 1155. See also J E Sandler, 'Lobbyists and Election Law: The New Challenge', in Luneburg, Susman \& Gordon, above n 15, 751, and the relative 'Update' in the Fourth Edition 2011 Supplement.

${ }^{35}$ Hasen, above n 3, 4.

${ }^{36}$ Deemed legitimate by Citizens United itself, which even relied on United States $v$ Harriss, above $\mathrm{n}$ 23, in its reasoning: Citizens United, above n 33, 103.

${ }^{37}$ Hasen, above n $3,24$.

${ }^{38}$ European Commission, An open and structured dialogue between the Commission and interest groups (1992) <http://ec.europa.eu/civil_society/interest_groups/docs/v_en.pdf> [accessed 25 July 2013].
} 
to any significant lobbying regulation for many years. A major change finally occurred in 2005, when the Commission launched the European Transparency Initiative (ETI) with an internal paper. ${ }^{39}$ This was followed by the 2006 Green Paper, which among other things focused on 'the need for a more structured framework for the activities of interest representatives (lobbyists). ${ }^{40}$ The Green Paper listed what in the Commission's view were the essential principles 'on which the relationship between the EU institutions and lobbyists should be built'. They are very significant for the purposes of this work, so it is worth quoting them all:

1. Lobbying is a legitimate part of the democratic system [...] 2. Lobbyists can help bring important issues to the attention of the European institutions. [...] 3. At the same time, undue influence should not be exerted on the European institutions through improper lobbying. 4. When lobby groups seek to contribute to EU policy development, it must be clear to the general public which input they provide to the European institutions. It must also be clear who they represent, what their mission is and how they are funded. 5. Inherent in the European institutions' obligation to identify and safeguard the 'general interest of the Community' is their right to hold internal deliberations without interference from outside interests. 6. Measures in the field of transparency must be effective and proportionate. $^{41}$

Two aspects of this passage are particularly relevant to the present analysis. The first one is the remarkable openness towards lobbying that the Commission shows in it: certainly, transparency is important, and disclosure requirements and rules of integrity (as the following paragraphs of the paper explain) are essential to achieve this goal; but in the words of the Commission there is no particular concern for the danger that lobbying could corrupt the integrity of the democratic process, a risk that even the dissenters in Harriss had acknowledged. ${ }^{42}$ The second point is that there is no mention of free speech: lobbying seems to be constructed

\footnotetext{
${ }^{39}$ European Commission, European Transparency Initiative, 9 November 2005 <http://ec.eur opa.eu/transparency/eti/index_en.htm > [accessed 25 July 2013].

${ }^{40}$ European Commission, above $\mathrm{n} 13$.

${ }^{41}$ Ibid, 5, citing Art 213 of the EC Treaty (now Treaty on the Functioning of the European Union, Art 245 , though the new treaty does no longer contain the relevant language).

${ }^{42}$ See especially in particular the words from Justice Jackson quoted supra (n 26).
} 
in a very different way than the American individualistic right to petition the government for a redress of one's own grievances. I will develop this observation in the conclusions (Part 4.2). There is a further aspect of the Green Paper that needs to be underlined. This is the point made by the Commission that it:

does not consider that a compulsory registration system would be an appropriate option. A tighter system of self-regulation would appear more appropriate. However, after a certain period, a review should be conducted to examine whether self-regulation has worked. If not, consideration could be given to a system of compulsory measures-a compulsory code of conduct plus compulsory registration.

Therefore, at least in principle, the Commission showed a clear preference for regulating lobbying by non-compulsory registration: it would be incorrect thus to consider this choice as a first-step, or an incomplete form of regulation, compared to the American model. Instead, the Commission made clear that, if such model produced satisfactory results, it would be content with it, and would not see the need for compulsory registration.

The Green Paper was followed the next year by a new policy paper, ${ }^{43}$ which launched a road map for the adoption of a common code of conduct and a new register for lobbyists. ${ }^{44}$ This document stressed 'once again that the Commission's definition of "lobbying" did not include any negative value judgment' and emphasised 'the legitimate and useful role of lobbying activities in a democratic system' 45 (even though, to avoid misunderstandings, the Commission chose to call the register, 'Register for Interest Representatives'). Then, in 2008, a new policy paper, still within the ETI framework, was adopted, containing a code of conduct and providing that breaches of it by the representative of a registered entity could lead to the suspension or exclusion of that entity from the Register. ${ }^{46}$

\footnotetext{
${ }^{43}$ European Commission, Follow-up to the Green Paper 'European Transparency Initiative', 21 March 2007 <http://ec.europa.eu/transparency/eti/docs/com_2007_127_final_en.pdf> [accessed 25 July 2013].

${ }^{44}$ Until then, only the CONECCS (Consultation, the European Commission and Civil Society) database existed, gathering the contributions received from interest groups during a consultation on a Commission's initiative; the paper provided for the discontinuing of such database.

${ }^{45}$ European Commission, above n 43, 3.

${ }^{46}$ European Commission, $A$ framework for relations with interest representatives (Register and Code of Conduct), 27 May 2008, <http://ec.europa.eu/transparency/docs/323_en.pdf> [accessed 25 July 2013].
} 
Furthermore, 'contributions to public consultations [by registered entities] will be published on the internet together with the identity of the contributor. ${ }^{47}$ The Register of Interest Representatives was opened on June 23, 2008. ${ }^{48}$

The European Parliament (EP) has also introduced its own regulation. Indeed, lobbying of this institution increased in intensity together with the increase of its powers: the more it became an essential player in the legislative process, the more it became the object of attention and pressure by lobbyists. ${ }^{49}$ As a result, the EP felt the need to discipline the relationships between them and its members. It did so in 1996, by introducing in its Rules of Procedure (then Rule 9(4)) a system of 'nominative passes valid for a maximum of one year [to be issued] to persons who wish to enter Parliament's premises frequently in order to supply information to members within the framework of their parliamentary mandate in their own interests or those of third parties. ${ }^{50}$ In return, those who requested a pass were required to respect a code of conduct and sign a register that was made available to the public. ${ }^{51}$ This framework was recently overhauled by the Transparency Register Agreement, ${ }^{52}$ which has finally brought about a joint register of lobbyists for the Commission and the Parliament. ${ }^{53}$ However, what we need to point out is that registration is still non-compulsory, and remains necessary only if lobbyists want to obtain long-term access to the EP premises-registration is not required for carrying out the job itself. After all, the Agreement is a non-legislative measure, and some legislative-type provision would be required to introduce a mandatory form of registration. The only other practical advantage in return for registering is the fact that the Commission will alert registered entities every time it publishes a new road map or launches a public consultation in the field that entity is interested in. If a lobbyist declines

${ }^{47}$ Ibid, 7.

${ }^{48}$ European Commission, <http://ec.europa.eu/news/justice/080623_1_en.htm> [accessed 25July 2013].

${ }^{49}$ W Lehmann \& L Bosche, Lobbying in the European Union: Current Rules and Practices, March 2003, <http://ec.europa.eu/civil_society/interest_groups/docs/workingdocparl.pdf > [accessed 25 July 2013], 33.

${ }^{50}$ Rules of Procedure of the European Parliament, <http://www.europarl.europa.eu/sides/getLast Rules.do?language $=$ EN\&reference $=$ TOC $>$ [accessed 25 July 2013].

${ }^{51}$ Ibid, Annex X, Art 3. Annex I also regulated the conduct of MEPs, and in particular their interests.

52 Transparency Register Agreement, above n 14.

53 European Parliament Rules of Procedure, above n 50, Rule 9 has been amended, in parallel. Annex X (retitled Transparency register) now contains in section A the Provisions governing the application of Rule 9(5) to (8) (dealing with the badges for interest representatives), and in section $\mathrm{B}$ the Transparency Register Agreement itself; Annex 3 to the Transparency Register Agreement contains the reformulated Code of conduct for lobbyists. 
to register, this does not currently have significant practical effects on his or her professional activities.

In the first Annual Report on the operations of the Transparency Register, it was revealed that '[a]s of 22 October 2012 there were 5431 registrants in the TR12 in total, of which almost half (48\%) have registered as Category II (In-house lobbyists and trade/professional associations) and about $28 \%$ in Category III (NGOs). ${ }^{54}$ We cannot conclude without mentioning a few statements made by the European Parliament in its decision to issue the inter-institutional agreement. ${ }^{55}$ First of all its reference to Article 11(2) TEU, according to which ' $t]$ he institutions shall maintain an open, transparent and regular dialogue with representative associations and civil society'. The principles of Article 11 were introduced by the Treaty of Lisbon and now sanction the necessity that the European institutions maintain an open dialogue with interest groups. ${ }^{56}$ But the EP also takes some positions that mark a distance with some of the views that the Commission expressed in the past: it explicitly describes the agreement as a 'first step towards greater transparency'; more to the point, it repeats its call for the mandatory registration of all lobbyists on the Transparency Register and calls for the necessary steps to be taken in the framework of the forthcoming review process in order to prepare for a transition to mandatory registration'. The Parliament is, therefore, clearly pushing towards the adoption of a US-style mandatory registration system, contrary to what has been-at least so far-the preferred option of the Commission. ${ }^{57}$ Finally, the Parliament also makes a significant call to the Council to adhere to the agreement: it 'regrets that the Council has not yet become a party to the agreement, although that is crucial in order to ensure transparency at all stages in the law-making process at Union level; welcomes, however, the fact that the Council has indicated that it will

\footnotetext{
${ }^{54}$ Joint Transparency Register Secretariat, 'Annual Report on the operations of the Transparency Register 2012', <http://europa.eu/transparency-register/pdf/transparency_register_report _20121029_en.pdf>, [accessed 25 July 2013], 9.

${ }^{55}$ European Parliament, European Parliament decision of 11 May 2011 on conclusion of an interinstitutional agreement between the European Parliament and the Commission on a common Transparency Register, 11 May 2011, <http://www.europarl.europa.eu/sides/getDoc.do?pub Ref $=-/ /$ EP//TEXT+TA+P7-TA-2011-0222+0+DOC+XML+V0//EN\#BKMD-35> [accessed 25 July 2013].

${ }^{56}$ For a study of lobbying in the EU after the Treaty of Lisbon, see especially K Joos, Lobbying in the new Europe (2011), Part 4 ('Lobbying at European Union institutions-framework and approaches'), 87-119.

${ }^{57}$ See D Obradovic, 'Regulating Lobbying in the European Union', in D Coen \& J Richardson (eds), Lobbying the European Union: Institutions, Actors and Issues (2009), 298-334, especially 319-320.
} 
become a party to the agreement; calls on the Council to join the common register as soon as possible'. Indeed, the absence of any sort of regulation for the lobbying of the Council is a remarkable gap, in a way comparable to the one that existed in the FRLA in the US, and it would be reasonable to expect that, exactly like in that country, it is eventually remedied, in this case by a voluntary act by the Council.

Admittedly, the lack of regulation as far as the Council, as well as the European Council, is concerned might be partially compensated by national regulations: by controlling how lobbyists influence the representatives of the respective member states to the Council, national lobbying rules indirectly provide a control over the decisions of this inter-state organ. However, this might not provide a sufficient amount of transparency for the EU nationals: partly because such rules are country-specific and therefore nationals of other member states might have difficulty in accessing the information relative to a country other than their own; partly because several member states essentially do not mandate transparency for lobbying activities brought about on their territory; and partly because even where transparency is sufficiently guaranteed at the national level, lobbying the national representatives to the Council is something rather different than lobbying the state government, and might easily not be covered by domestic regulations. Therefore, a comprehensive regulation of lobbying in the EU would mandate at least full disclosure of all 'lobbying contacts' (to use the phrase adopted by American law) between interest representatives and Council and European Council members and staff, ${ }^{58}$ and possibly some 'revolving door' ban.

\footnotetext{
${ }^{58}$ On the crucial importance of disclosure, a policy goal usually enjoying bipartisan support from even opposite sides of the political spectrum, see T E Mann, 'Lobbying Reform: Accountability through Transparency', Testimony before the Committee on Rules of the US House of Representatives, 2 March 2006, <http://www.brookings.edu/research/testimony/2006/03/02governance-mann> [accessed 25 July 2013].
} 


\section{Protecting freedom or democracy?}

\subsection{A free speech exception?}

The traditional account of the protection of free speech in the US and in Europe describes the former as the land of Madison's, ${ }^{59}$ Tocqueville's ${ }^{60}$ and Mill's ${ }^{61}$ spirit, while the latter as more concerned with balancing individualistic freedom of expression and associational rights with the need to protect democracy.

Madison subscribed to the view that letting all voices be heard, thus making 'ambition [...] to counteract ambition, ${ }^{62}$ is preferable to silencing all voices, lest the most powerful of them should drown the weak ones and have too much influence. His assumption was that there was more to be gained from leaving special interests free to speak against each other, even if this came at the cost of allowing some room for excesses and corruption, than from insulating public officials from all influence, thus making them decide without listening to the views of the concerned and competing parties. As Madison wrote:

Extend the sphere, and you take in a greater variety of parties and interests; you make it less probable that a majority of the whole will have a common motive to invade the rights of other citizens; or if such a common motive exists, it will be more difficult for all who feel it to discover their own strength, and to act in unison with each other. Besides other impediments, it may be remarked, that where there is a consciousness of unjust or dishonorable purposes, communication is always checked by distrust, in proportion to the number whose concurrence is necessary. ${ }^{63}$

Tocqueville famously described the considerably beneficial effect for the American society arising from the existence in the US of such a great number of active associations and groups, pursuing the most disparate interests. As Tocqueville observed:

\footnotetext{
${ }^{59} \mathrm{~J}$ Madison, The Federalist No. 10 (1787). See also J Madison, The Federalist No. 51 (1788). For some reflections on Madison's thought in connection to lobbying law, see A S Krishnakumar, "Towards a Madisonian, Interest-Group-Based, Approach to Lobbying Regulation' (2007) 58 Alabama LRev 513.

${ }^{60}$ See especially Alexis de Tocqueville, Democracy in America, vol 1 (1835), ch 12; A de Tocqueville, Democracy in America, vol 2 (1840), ch 5, 6, 7.

${ }^{61}$ Cf J S Mill, On Liberty (1869), ch 2 (for the notion of 'marketplace of ideas').

${ }^{62} \mathrm{~J}$ Madison, The Federalist No. 51 (1788).

${ }^{63}$ J Madison, The Federalist No. 10 (1787), para 63.
} 
When once the right of association is recognized, the citizens may employ it in several different ways. An association consists simply in the public assent which a number of individuals give to certain doctrines, and in the engagement which they contract to promote the spread of those doctrines by their exertions. ... When an opinion is represented by a society, it necessarily assumes a more exact and explicit form. It numbers its partisans, and compromises their welfare in its cause: they, on the other hand, become acquainted with each other, and their zeal is increased by their number. An association unites the efforts of minds which have a tendency to diverge in one single channel, and urges them vigorously towards one single end which it points out.

The second degree in the right of association is the power of meeting. When an association is allowed to establish centres of action at certain important points in the country, its activity is increased and its influence extended. [...]

Lastly, in the exercise of the right of political association, there is a third degree: the partisans of an opinion may unite in electoral bodies, and choose delegates to represent them in a central assembly. This is, properly speaking, the application of the representative system to a party.

Thus, in the first instance, a society is formed between individuals professing the same opinion, and the tie which keeps it together is of a purely intellectual nature; in the second case, small assemblies are formed which only represent a fraction of the party. Lastly, in the third case, they constitute a separate nation in the midst of the nation, a government within the Government. Their delegates, like the real delegates of the majority, represent the entire collective force of their party; and they enjoy a certain degree of that national dignity and great influence which belong to the chosen representatives of the people. ${ }^{64}$

Along similar lines, chapter two of Mill's masterpiece, 'On Liberty', 'is most famous for being the definitive exposition of the (social) epistemic arguments for freedom of expression-the ways in which freedom of expression functions as an

${ }^{64}$ de Tocqueville, above $\mathrm{n} 60$, ch 12. 
indispensable aid in the societal identification of truth (and exposure of falsity), and, thus, in the fostering of public knowledge. ${ }^{65}$ In Mill's own words:

Not the violent conflict between parts of the truth, but the quiet suppression of half of it, is the formidable evil: there is always hope when people are forced to listen to both sides; it is when they attend only to one that errors harden into prejudices, and truth itself ceases to have the effect of truth, by being exaggerated into falsehood. And since there are few mental attributes more rare than that judicial faculty which can sit in intelligent judgment between two sides of a question, of which only one is represented by an advocate before it, truth has no chance but in proportion as every side of it, every opinion which embodies any fraction of the truth, not only finds advocates, but is so advocated as to be listened to. ${ }^{66}$

The right to freely express one's ideas is thus seen as beneficial for the whole society, because the competition and even clash of different ideas is the most effective way to let the better ideas emerge and prevail over the worse. This line of thought famously influenced all the First Amendment jurisprudence in the US, but such influence was made possible by a constitutional background very fertile to its taking root. The American Bill of Rights allowed such a jurisprudence to develop because it had been conceived in a relatively virgin institutional environment: in the newly-established United States, the federal government was still very limited, and this allowed the establishment of clear, absolute principles with a strong idealistic value.

Europe, on the other hand, is usually portrayed as less 'Madisonian': free speech is obviously strongly protected by all the existing catalogues of rights in Europe too, but it does not play the 'sacred' role that it plays in the US, where the almost absolute protection afforded to the freedom of speech shapes the way American democracy itself is constructed. We need to be careful not to oversimplify in tracing back the historical reasons for this difference to one single event or to the influence of one single author. If we had to pick up one reference, however, it would be inevitable to mention Rousseau and his well-known idea of the dangers for the common good of the society inherent in the pursuit by

\footnotetext{
${ }^{65}$ F Schauer, 'On the Relation Between Chapters One and Two of John Stuart Mill's On Liberty' (2011) 39 Capital ULR 1, 5-6.

${ }^{66}$ Mill, above n 61, ch 2.
} 
everyone of their own selfish interests. ${ }^{67}$ As Rousseau writes in a paragraph on democracy in 'The Social Contract':

Nothing is more dangerous than the influence of private interests in public affairs, and the abuse of the laws by the government is a less evil than the corruption of the legislator, which is the inevitable sequel to a particular standpoint. In such a case, the State being altered in substance, all reformation becomes impossible. ${ }^{68}$

Undoubtedly, the tragic experience of totalitarianism also influenced the European approach to the protection of free speech, particularly when such speech threatens the survival of democracy. So Europe in general never protected the freedom of expression of terrorists, political extremists, racists, holocaust deniers, and the like, at least not to the same extent as America did. ${ }^{69}$ Instead, European courts developed proportionality analysis and used it to balance the freedom of expression with the need to safeguard democracy; ${ }^{70}$ similarly, legislators passed laws aimed at punishing those manifestation of thought that run counter to the basic tenets of liberal democracy, thus endangering its very survival. ${ }^{71}$ Along the same lines, German constituents famously incorporated the principle of 'militant democracy' in the Basic Law, archetypal of a certain way of conceiving democracy, and of the need to establish legal (chiefly constitutional) safeguards to protect it. ${ }^{72}$ Article 10 of the European Convention on Human

${ }^{67}$ See generally J J Rousseau, Discourse on Political Economy (1755); J J Rousseau, The Social Contract (1762).

${ }^{68}$ Rousseau (1762), above n 67, Book III, $\$ 4$.

${ }^{69}$ Suffice it to recall leading cases, e.g. Brandenburg v Ohio, 395 US 444 (1969); Cohen v California, 403 US 15 (1971); New York Times Co v United States [The Pentagon Papers Case], 403 US 713 (1971); Texas v Johnson, 491 US 397 (1989); RAV. v City of St Paul, 505 US 377 (1992); Virginia v Black, 538 US 343 (2003).

${ }^{70}$ On proportionality analysis, see e.g. A Stone Sweet \& J Mathews, 'Proportionality Balancing and Global Constitutionalism' (2008-2009) 47 Col J of Trans L 72; M Cohen-Eliya \& I Porat, 'American balancing and German proportionality: The historical origins' (2010) 8 Int J of Const $L 263$.

${ }^{71}$ E.g. Council Framework Decision 2008/913/JHA of 28 November 2008 on combating certain forms and expressions of racism and xenophobia by means of criminal law, OJ $2008 \mathrm{~L} 328 / 55$, on which see J J Garman, 'European Union Combats Racism and Xenophobia by Forbidding Expression: An Analysis of the Framework Decision' (2007-2008) 39 U of Toledo LRev 843.

${ }^{72}$ See S Avineri, 'Introduction', in A Sajó (ed), Militant Democracy (2004), 1. The term 'militant democracy' (Streitbare Demokratie, perhaps better rendered as 'fighting democracy') was coined and popularised by the German émigré scholar Karl Loewenstein in a series of two articles published in 1937: K Loewenstein, 'Militant Democracy and Fundamental Rights I' (1937) 31 The 
Rights is phrased in terms of need to balance the freedom of expression with the need to protect democracy:

1. Everyone has the right to freedom of expression. This right shall include freedom to hold opinions and to receive and impart information and ideas without interference by public authority and regardless of frontiers. This Article shall not prevent States from requiring the licensing of broadcasting, television or cinema enterprises.

2. The exercise of these freedoms, since it carries with it duties and responsibilities, may be subject to such formalities, conditions, restrictions or penalties as are prescribed by law and are necessary in a democratic society, in the interests of national security, territorial integrity or public safety, for the prevention of disorder or crime, for the protection of health or morals, for the protection of the reputation or rights of others, for preventing the disclosure of information received in confidence, or for maintaining the authority and impartiality of the judiciary. ${ }^{73}$

While the constitutional moment in the US happened when the government was light and its perimeter narrow, the post-World War II wave of constitutionalism in Europe took place when the state had decidedly expanded, and the institutional background was much more developed. Therefore, the protection of freedom of expression was (re)born in a context heavily influenced by positive law and thus with inevitable limitations. These few hints were just to suggest that it would have been reasonable to expect that, consistently with this framework, Europe would have paid more attention to the need to safeguard democracy also in the field of lobbying, and consequently would have enacted legislation that at least balanced this exigency with the one of allowing the freedom to communicate and to exert pressure on public officials. Yet the picture we have drawn is quite different. This can be quite surprising at first sight. Indeed one could expect a syllogism like this: a) no fundamental right, in Europe or elsewhere, is protected with the same intensity as free speech rights are protected in the US; (b) (even though with the caveats of Part 3.2) lobbying in the US falls within the free speech realm; (c) therefore, lobbying should not be as protected anywhere as it is in the US. However, after reviewing the EU law of lobbying, we learned that lobbying

American Political Science Rev 417; and K Loewenstein, 'Militant Democracy and Fundamental Rights II' (1937) 31 The American Political Science Rev 638.

${ }^{73}$ Emphasis added. 
in the EU, even after the recent overhaul, is an almost unregulated activity: the reforms of May 2011, however significant, still do not set up a mandatory system of registrations for those who engage in this activity.

We saw that it would be inappropriate to explain the choice of the EU, so far, not to regulate lobbying through compulsory requirements, with the fact that the EU has only recently experienced the growth of a lobbying industry to an extent comparable to the US level. Indeed, even if such an account has been suggested by the Parliament itself in its May 2011 decision, which reaffirmed its view of the need to introduce a system of mandatory registration, ${ }^{74}$ the Commission took the opposite view-so far that view has prevailed. Apparently, then, we may be faced with an unexpected 'free speech exception', namely of having found an area of free speech that departs from the usual lines, the lines of a US that protects free speech to the maximum extent, and of a Europe more willing to balance its protection with the perceived needs of democracy. Apparently, the regulation of lobbying would follow a different track. But is that really the case?

\subsection{Freedom or democracy: two different reasons for protecting lobbying}

To be sure, even admitting, arguendo, that Part 4.1's stylized description of free speech protection in the US and the EU is accurate, such a hypothesised 'free speech exception' is based on a faulty assumption, i.e. that the reasons for protecting lobbying are the same in both the legal systems. I demonstrated that things are quite different: in no EU document is there a reference to the freedom of expression as the constitutional basis for protecting lobbying. Instead, the Commission clearly indicated another constitutional ground: the promotion of a well-functioning (participatory) democracy, giving voice to all the stakeholders who want to be involved in the decision-making process. Certainly, American and European law share very similar definitions of 'lobbying' (as was analysed in Part 2), and the activity itself to which these definitions refer to is substantially the same: in both cases, lobbying is looked at as the enterprise of 'stably intermediating' between the polity and the legislators/regulators.

However, the way constitutional law looks at lobbying is significantly different on the two sides of the Atlantic. The US considers it a form of expression (whether it is characterised as speech, association, or petition), ${ }^{75}$ by which natural

\footnotetext{
${ }^{74}$ European Parliament, above $n 55$.

${ }^{75}$ See N W Allard, 'Lobbying is an Honorable Profession: The Right to Petition and the
} 
and legal ${ }^{76}$ persons pursue their own individualistic goals and interests before public decision-makers. On the one hand, this aids development of a healthy democracy, given the assumption that a sort of 'invisible hand' will lead the pursuit of selfish goals to maximise general utility in the political realm, ${ }^{77}$ and considering that the fact that this is done through professionally trained stable intermediaries who help individual interests to be transmitted effectively to democratic venues. Still, lobbying remains first of all a fundamental freedom of the individual (or the corporation), acting in pursuit of his (or its) selfish benefit.

In the EU, it is the other way around. The European Commission's Green Paper and other European documents described above consider lobbying functional to democracy, and the reason to protect it is the beneficial contribution of knowledge and expertise it can bring to decision-making by European institutions. Lobbying may certainly be seen as a form of political expression, but in the EU it remains first of all an activity that serves the goals of participatory democracy, now epitomised in Article 11 TEU: here, the stable intermediation exercised by lobbyists is strategic to the institutional model of communicating opinions and needs from the special interests to the policy-makers. If that is true, the apparent puzzle is solved. Indeed, in Europe the democratic principle arguably underpins the whole legal system, comparable to the centrality of free speech in American constitutional discourse. We can then identify a different syllogism: a) Europe is built around the inspiring principle of democracy; b) lobbying in the EU is interpreted as a way to fulfill the principle of (participatory) democracy, and c) therefore, lobbying in the EU understandably enjoys a very strong level of protection. Admittedly, the Parliament has pleaded for the introduction of some restrictions on this activity, in the form of mandatory registration, disclosure, and rules of conduct. This does not, however, change the fact that, in the EU, both the reasons for protection and the reasons for restriction fall in the realm of the democratic principle. So far, the reasons for protection have outweighed those for restriction. However, there seems to be a growing sense that a different balance needs to be struck, as advocated by the EP. Similarly,

Competition to Be Right' (2008) 19 Stan L \& Policy Rev 23, 36-42; E Garrett, R M Levin \& T Ruger, 'Constitutional Issues Raised by the Lobbying Disclosure Act', in Luneburg, Susman \& Gordon (eds), above n 15, 197-222, and the 'Update' in the Fourth Edition 2011 Supplement; Browne, above $\mathrm{n} 25$; Thomas, above $\mathrm{n} 25$.

${ }^{76}$ Citizens United, above n 33, famously affirmed that the First Amendment rights of corporations (and unions) must enjoy the same protection as the free speech rights of individuals.

${ }^{77}$ Garrison v. Louisiana, 379 US 64 (1964), 74-75 ('speech concerning public affairs is more than self-expression; it is the essence of government'). 
in the US a movement has arisen calling for tightening of he existing rules. When it comes to this, the respective constitutional grounds for protecting lobbying are crucial in determining how far regulation can go.

There is another aspect. The very structure of the respective legal systems plays an important role in shaping the constitutional arguments for the protection of lobbying in the US and in Europe. The intrinsic flexibility of the American common law system creates large opportunities for lobbying as a way to participate in shaping the execution of the law. ${ }^{78}$ As was captured by Jefferson in a famous dictum of his, " $t$ ] he execution of the laws is more important than the making of them': ${ }^{79}$ and in a common law system like the US, lobbying has particular room to shape such execution. Both the law-making and the law-execution are therefore more open to contributions by external actors. Specifically on the former, it can be added that the legislative process characteristic of the American system might seem to entrust the rule-making job to the contest among contrasting interests: apparently, 'stable intermediaries' able to influence the relationship between such interests and the law-makers do not fit into this scheme. However, these intermediaries have grown to become the agents of special interest, their actual substitutes, so their presence does not really alter the common law model of law-making: they no longer are truly outside actors, rather they identify themselves with the interests they represent to the point that they become genuinely part of the game.

On the other hand, continental European legal systems turn out to be more rigid, influenced by the view that the primary law-making body is the parliamentary assembly: lobbying certainly exists at the executive level too, but it is traditionally more constrained, and it tends to be focused principally on the law-maker. Moreover, the law-making there tends to be more impermeable to external contributions, in the end leaving less room for outside actors to come to play on the parliamentary field. One might think that civil-law systems are more inclined to accommodate the role of stable intermediaries as advisers of the law-makers, given that their constituencies traditionally have less access to legislators than in Anglo-Saxon countries, and therefore some regular connection with the constituency needs to be established. Nonetheless, at a closer look, the civil law law-making system ends up insulating in a way legislators from the polity, thus making the task of bridging the gap between them harder to perform. This might account, at least in part, for the great protection of lobbying that

\footnotetext{
${ }^{78}$ See J R Straus, Lobbying the Executive Branch: Current Practices and Options for Change (2011).

${ }^{79}$ S K Padover (ed), Thomas Jefferson on Democracy (1953) 152 (Letter to Abbe Arnond, 1789).
} 
we have observed at the European level. For the institutional reasons hinted at here, in civil law systems lobbying has less room to develop. This might explain why lobbying arose at a later time in Europe and why Europe tends to afford protection to lobbying to such a great extent: it will never go beyond certain borders anyway.

This brings us to a further point: so-called grassroots lobbying, typically brought about for idealistic and non-economic reasons, is far more developed in the US than in Europe. ${ }^{80}$ One plausible explanation from the institutional and constitutional point of view is that the American legal system leaves more room for lobbying practiced at different levels: the fact that lobbying can be conducted in multiple fora provides more opportunities for practicing it. In this 'market' the opportunity for idealistic, grassroots lobbying arises, while in the more constrained European environment the market for lobbying tends to be monopolised by economically motivated players.

If we look in particular at lobbying at the legislative level, a further difference relates to the power of Congressional committees in the US. These committees play a key role in the legislative process ${ }^{81}$ and this gives their individual members great power, which creates a strong incentive for lobbyists to win their favour. The situation is different in the European Parliament; due to the use of the so-called trilogues (informal meetings held during the legislative process in the EU, attended by representatives from the Council, the Parliament and the Commission), committees and individual legislators have less power than their American counterparts. ${ }^{82}$ This reduces the concern that lobbyists might distort the law-making process, possibly explaining the lighter-touch approach that we have seen.

Finally, and connected to this, one last aspect to consider is the level of party discipline in the two legal systems reviewed. The European Parliament has maintained the high level of party discipline typical of the individual EU

\footnotetext{
${ }^{80}$ At least so far: recent restrictions introduced by the Obama administration have arguably harmed non-profit advocacy: see Center for Lobbying in the Public Interest, Collateral Damage. How the Obama Administration's Ethics Restrictions on Public Service Have Harmed Nonprofit Advocacy and the Public Interest (2011).

${ }^{81}$ See AJ Mikva \& E Lane, Legislative Process (3rd edn, 2009), 123-208. It has to be at least mentioned, though, that over the recent years, the traditional centrality of the committees in the US Congress has been partly giving way to a more European-style system of party-discipline: see generally $\mathrm{T}$ E Mann \& N J Ornstein, The Broken Branch: How Congress Is Failing America and How to Get It Back on Track (2006).

${ }^{82}$ See R Kardasheva, 'Trilogues in the EU Legislature' (2012), <http://raya.eu/wp-content/up loads/2012/08/Trilogues_in_the_EU_Legislature.pdf>, [accessed 25 July 2013], 4ff.
} 
member states. An interesting study published in 2008, whose first results were presented more than ten years ago (at the 2001 Annual Meeting of the American Political Science), ${ }^{83}$ showed that party discipline in the European Parliament was remarkable even at the beginning of the life of this organ, and has substantially increased in parallel with the growth of the powers entrusted to such assembly. ${ }^{84}$ Even in the absence of a party whip system as rigid as the one in place in European parliamentary democracies, this was realised through the appointment of the most loyal MEPs in the most prestigious committees (admittedly, committee membership affords less power to legislators in the EU than in the US, as was just said, but appointment in the most important committees is anyway a valued reward). The situation in the US is very different: political parties have much less control over the selection of the candidates and over the behaviour of Congressmen. A candidacy tends to be more of an individual enterprise, not controlled by political parties, and this reflects on how candidates behave once elected, namely party discipline is much less stringent here. As a result, there would seem to be a higher incentive for pressure groups to lobby individual members of Congress, while in the European Parliament it is essentially the group leaders' favour that has to be won. This creates more opportunities for lobbying in the US, and would seem to account for the relatively minor concern showed by European institutions in allowing virtually unrestricted lobbying of single MEPs.

\section{Conclusion}

The comparison drawn leads me to submit first of all that the different constitutional underpinnings of lobbying protection would let the EU go further than the US in regulating it. Indeed, the role played by the First Amendment rights in the US cannot tolerate burdens to a greater extent than the one declared legitimate in Harriss. In fact, the traditional rationale relied on in that case may not even hold any more: the LDA already based the justification of its restrictions on the need to inform the public, rather than Congress (as in Harriss's reasoning); ${ }^{85}$ more importantly, the two cases of the Citizens United progeny mentioned at the end of 3.1. 'should be viewed like a canary in the coal mine, signalling that lobbying laws

${ }^{83} \mathrm{G}$ McElroy, 'Committees and Party Cohesion in the European Parliament' (2001), <http://www2.lse.ac.uk/government/research/resgroups/EPRG/pdf/workingPaper8.pdf> [accessed 25 July 2013].

${ }^{84}$ G McElroy, 'Committees and Party Cohesion in the European Parliament' (2008) 37 Österreichische Zeitschrift für Politikwissenschaft 357.

${ }^{85}$ Hasen, above n 3, 18-19, citing 2 USC 1601; Garrett, Levin \& Ruger, above n 74, 198. 
that were once seen as easily passing constitutional muster now face a potentially difficult path., ${ }^{86}$ Legislators will then have to be very careful in limiting lobbying by selecting the less restrictive alternative, otherwise the Supreme Court may eventually strike them down for breach of the First Amendment guarantees. In Europe, on the other hand, the sole consideration is the democratic principle, and therefore regulation could potentially even forbid certain lobbying activities, if it were deemed that this would better serve the democratic principle: no 'constitutional' obstacle would prevent this.

One should, indeed, never overlook the historical roots lying behind the regulatory choices of the two areas under consideration: as I have tried to show, legal history explains a lot of the current regulatory framework in the lobbying field, and warns Europe against simply importing rules from overseas. The inner characters of common law and civil law influence how and to what extent lobbying can develop and should always be taken into account when legislating on the subject. This fundamental caveat, however, does not mean that the American law of lobbying could not be taken as a useful model by European institutions, and therefore that comparing the two constitutional and regulatory schemes is sterile. In fact, if we look at other countries that have regulated lobbying, ${ }^{87}$ there are certainly many important variables, but the core structure tends to be very similar, with the recurring presence of registration and disclosure obligations, plus some form of 'revolving door' limitation; and this is due to the fact that the essence of lobbying tends to be everywhere the function of 'stable intermediation' between special interests and policy-makers, that was shown as a constant factor in the previous analysis. The American law has, indeed, been a model for several other countries, so looking at the LDA for inspiration would be the most natural of choices for Europe. In summary, as always when comparing the lobbying law of the two systems and assessing the practicability of an imitation of American regulation by the Europeans, it should never be overlooked that 'much more than legal rules needs to be subject to comparison': ${ }^{8}$ in adherence to this precept, mine has been an attempt to shed a little light on the respective constitutional, theoretical, and more broadly cultural backgrounds of lobbying regulation in the two areas considered.

\footnotetext{
${ }^{86}$ Hasen, above n 3, 24.

${ }^{87}$ See e.g. R Chari, J Hogan \& G Murphy, Regulating Lobbying: A Global Comparison (2010).

${ }^{88} \mathrm{R}$ Cotterrell, 'Comparative Law and Legal Culture', in M Reimann \& R Zimmermann (eds), The Oxford Handbook of Comparative Law (2006), 709, 710.
} 